\title{
A Virtual Resource for Enhancing the Spatial Comprehension of Crystal Lattices
}

\author{
Diego Vergara ${ }^{1, *}$, Manuel Pablo Rubio ${ }^{2}$ and Miguel Lorenzo ${ }^{3}$ (B) \\ 1 Technological Department, Catholic University of Ávila, 05005 Avila, Spain \\ 2 Construction Department, University of Salamanca, 37008 Salamanca, Spain; mprc@usal.es \\ 3 Department of Mechanical Engineering, University of Salamanca, 37700 Salamanca, Spain; \\ mlorenzo@usal.es \\ * Correspondence: diego.vergara@ucavila.es or dvergara@usal.es; Tel.: +34-920-251-020
}

Received: 31 July 2018; Accepted: 18 September 2018; Published: 21 September 2018

\begin{abstract}
Students commonly exhibit serious spatial comprehension difficulties when they come to learning crystal systems. To solve this problem, an active methodology based on the use of a Didactic Virtual Tool (DVT) — developed by the authors—is presented in this paper. The students' opinion was obtained from a survey carried out on 40 mechanical engineering students. The analysis of the obtained results reveals that, by using this DVT, students achieve a better understanding of the contents where spatial difficulties often arise during conventional teaching. Several DVT features were highly valued by the students, e.g., didactic use was rated 9.5 out of 10 and the methodology using the DVT in the classroom was rated 8.5 out of 10 . In addition, the results revealed two factors that the students considered essential for using a DVT, both related to the tool design: (i) the modern aspect, i.e., it is necessary to keep a DVT updated to avoid obsolescence; and (ii) the DVT must be appealing in order to attract the students' attention.
\end{abstract}

Keywords: crystal system; Bravais lattices; spatial abilities; didactic virtual resources; didactic virtual tools; design; active methodology

\section{Introduction}

One of the key contents in most of the subjects related to Materials Science and Engineering is the spatial atoms arrangement in crystal systems [1-5]. Commonly, this topic is of the highest interest for engineering and chemical students. However, diverse shortcomings related to the spatial vision arise: the visualization of a spatial atom arrangement from different points of view; the visualization of the cross sections that identify the atomic arrangement from different points of view; visualization of the positions of the octahedral and tetrahedral interstitial sites of the crystal systems; etc.

Previous papers highlighted how important and necessary it is to acquire a good spatial visualization skill for the future professional life of an engineer or architect [6]. In this sense, serious spatial visualization difficulties in technical or engineering subjects were detected [7-10]. On the other hand, the advantage of using virtual tools (VTs) in the teaching of subjects included in engineering degrees have been demonstrated many times [11-14]. Thus, teaching experiences carried out with engineering students revealed that an improvement of both the acquired knowledge and spatial visualization skill are achieved by using a VT. This is in agreement with previous studies [15-20] where it was demonstrated that the visualization skill can be improved through appropriate training. Taking all the previously mentioned into account, two facts can be stated: (i) the graphical design of any Didactic Virtual Tool (DVT) is a key factor in achieving an educative aim; and (ii) in the case that such a tool is used for solving any spatial visualization problem, the tool design becomes an even more influential factor. 
Regarding the topic of this paper-spatial visualization of atom arrangement in crystal systems-several examples of didactic apps using Information and Communication Technologies (ICTs) exist [21-24]. Some of them are available on open-access websites [25]. The DVT presented in this paper is based on a 2D environment, but this DVT includes the features of a 3D interaction in real time with the crystal systems, i.e., students can freely interact with all the crystal systems in order to spatially understand the position of each atom within the lattice. In this way, the potential problems involved in spatial visualization related to this type of teaching are solved. This type of interactivity is really important from the teaching point of view, according to previous studies that revealed a link between this feature and the students' interest in learning [26].

As a summary, this paper presents a teaching methodology based on a DVT which can be applied to the teaching of crystal systems in engineering degrees. Furthermore, the students' opinions are reflected, revealing a link between the DVT design and the motivation generated in the students for continuing to use the DVT.

\section{Didactic Virtual Tool (DVT)}

The DVT presented in this paper was designed using Unity ${ }^{\circledR}$. This commercial software allows the development of videogames and 3D interactive applications in real time. Nowadays, many types of software can be used for designing interactive tools in real time, e.g., Quest3D ${ }^{\circledR}$, OGRE $^{\circledR}$, GameStudio $^{\circledR}$, etc. Among them, the authors selected Unity ${ }^{\circledR}$ as it offers the following advantages: (i) Unity ${ }^{\circledR}$ offers content for diverse platforms such as PC, Mac, Nintendo, Wii, and most of all, IOS (Iphone) and Android (in the present day, Android is the most used platform on mobile devices or tablets); (ii) it allows a high variety of script languages for programming; (iii) modular application growth is allowed; (iv) the software documentation is complete; (v) it offers a free licence, this way applications can be developed free of charge from the beginning.

The developed DVT was designed from the teaching flow shown in Figure 1. According to this, the didactic contents included in the DVT appear in a logical sequence in various screens. The main screen helps students to understand and to visualize the differences between the different types of atom arrangements in metals (seven crystal systems). From this screen, students have access to the different subclasses, completing the 14 Bravais Lattices. In each one of them, four visualization modes are available for enhancing the interaction between student and DVT: the unit cell with two visualization options (real and expanded), and the global lattice (several unit cells assembled) also with real and expanded views.

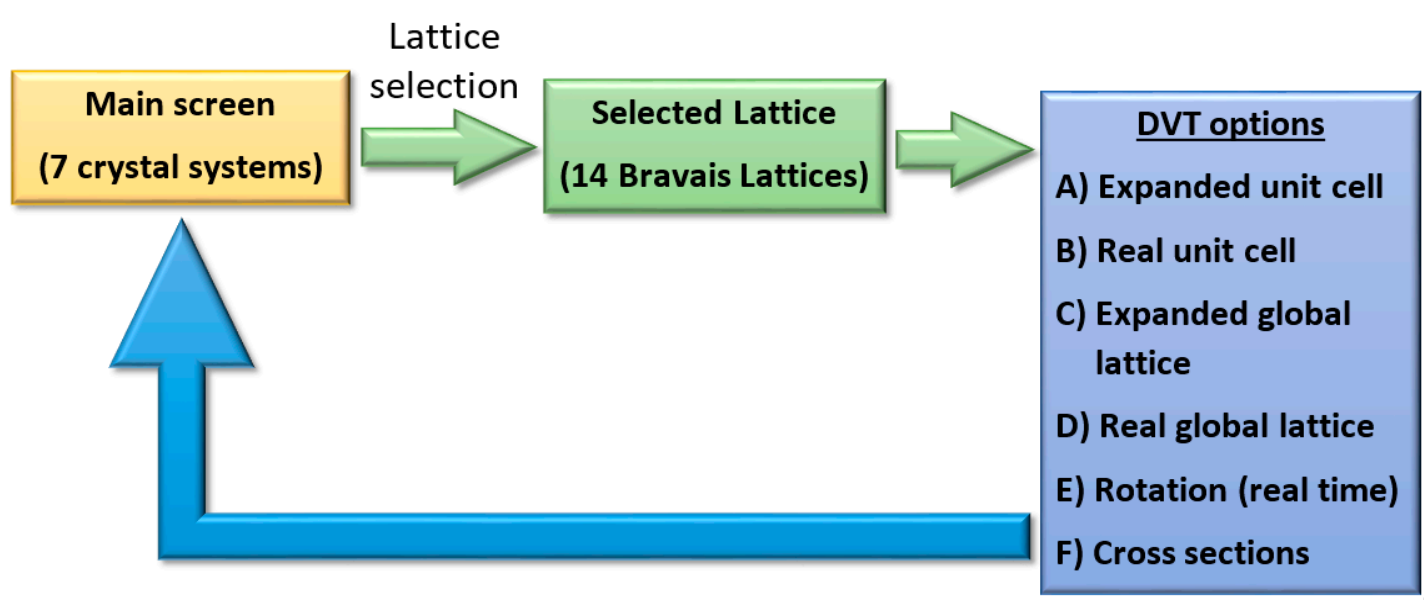

Figure 1. Didactic virtual tool (DVT) teaching flow.

According to the authors' teaching experience, these visualization options are useful for achieving a better understanding of the spatial visualization of the crystal systems. On one hand, the unit cell 
helps students to understand the placement of atoms individually, and on the other hand, the global lattices are useful for understanding the crystal system as a whole. For each one of 14 Bravais lattices, the expanded view is the first approach that makes the understanding easier, but the real view visualization option is the one that students must understand as a final goal. The different lattice types are ordered in the DVT from the easiest to the more complex with the four visualization options available: (i) expanded unit cell; (ii) real unit cell; (iii) expanded global lattice; and (iv) real global lattice. In addition, for each one of the 14 Bravais lattices, students can rotate and make cross sections of the crystal lattice in order to enhance the spatial visualization. In this way, students can visualize and easily understand the spatial arrangements of atoms in the diverse crystal systems from the simplest to the most complex by themselves.

Figure 2 shows the DVT main screen including the seven crystal systems: (i) Cubic; (ii) Tetragonal; (iii) Orthorhombic; (iv) Rombohedral or Trigonal; (v) Hexagonal; (vi) Monoclinic; and (vii) Triclinic. By clicking on any of them, a new screen appears revealing the respective 14 types of Bravais lattice: (i) Simple Cubic, BCC, and FCC; (ii) Simple Tetragonal and Body Centred Tetragonal; (iii) Simple Orthorhombic, Body-Centred Orthorhombic, Face-Centred Orthorhombic and Base-Centred Orthorhombic; (iv) Rombohedral; (v) Simple Hexagonal; (vi) Simple Monoclinic and Base-Centred Monoclinic; (vii) Triclinic. As an example, Figure 3 shows the three cubic crystal systems which appear after clicking the cubic system button on the main screen (Figure 1): (i) simple cubic; (ii) body centred cubic (BCC); and (iii) face centred cubic (FCC). In this way, students can explore the fourteen possibilities of atom arrangement in 3D (Bravais Lattices) included in the seven different crystal systems (main screen) on their own.

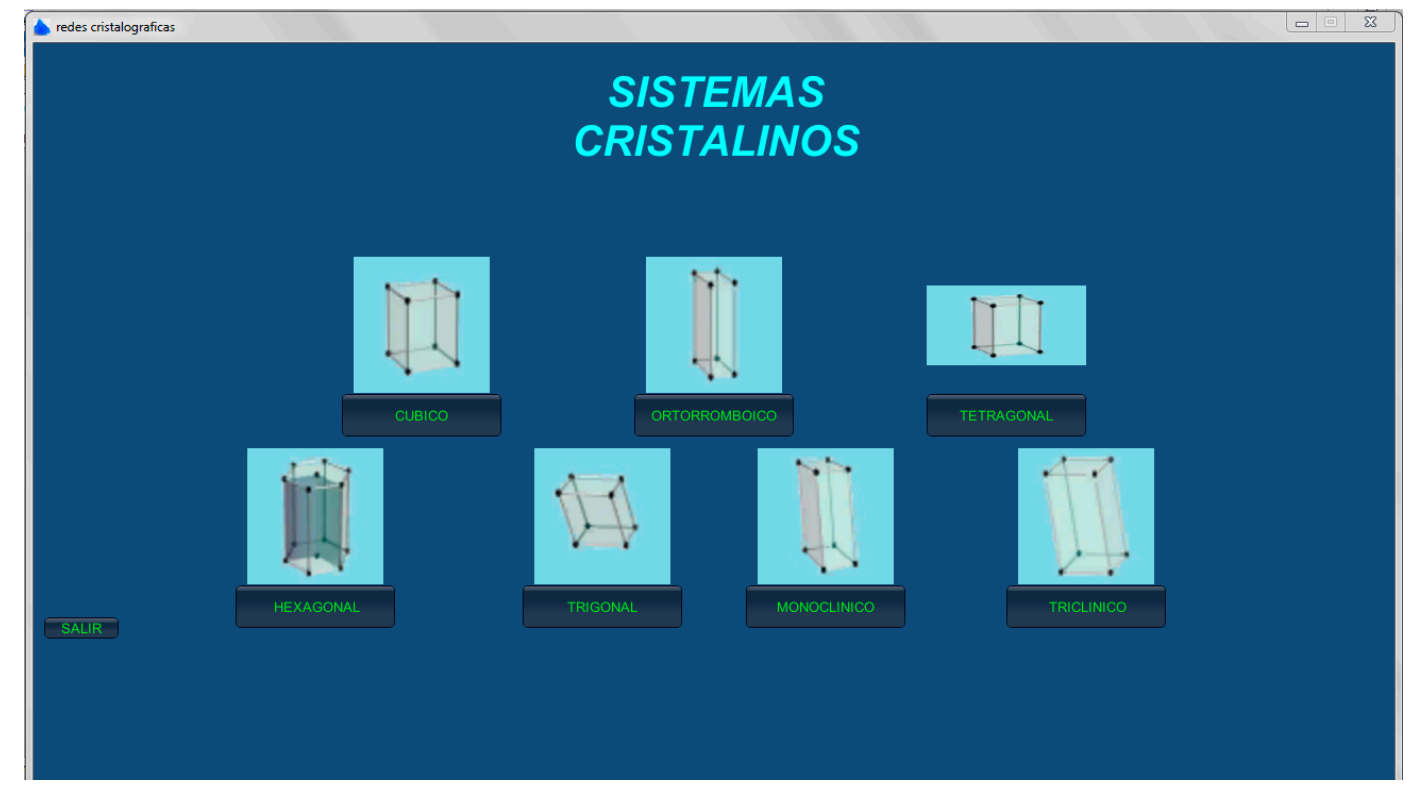

Figure 2. Main screen of the Didactic Virtual Tool showing the seven crystal systems.

The study of crystal lattices is included in the course of all subjects related to Materials Science and Engineering. Thus, the DVT includes the common crystal lattice classifications used in any textbook of Materials Science and Engineering [1-5]. It is necessary to highlight that the common hexagonal close-packed structure (HCP) is not included here since, according to the textbooks, this one cannot be classified within the hexagonal crystal system: "the so-called HCP does not correspond to the hexagonal system, since this one only admits a simple cell. In fact, it is equivalent to a simple rombohedric cell, easier to be represented" (sentence translated from Spanish in Reference [27] (p. 46)).

By using the DVT, users can search for any of these crystal systems and their respective lattices in an easy and intuitive way. In the DVT, the atomic arrangement in crystalline solids is represented 
placing atoms in the interaction points of a three-dimensional structure with virtual lines (expanded unit cell, Figure 4). In this way, the spatial understanding of the crystal systems in the initial stages is simplified and the teaching becomes easier. Once the atoms arrangement is understood, the DVT serves for visualizing the real atoms position, in which the atoms are in contact with each other (real unit cell, Figure 5a), and even for visualizing the complete crystal lattice formed by several unit cells (real global lattice, Figure 5b). This DVT also includes theoretical information relevant to each unit cell (see the right upper side on Figure 4): geometrical data of the angles and sides of the unit cell, coordination number, atomic packaging factor, and number of atoms per cell.

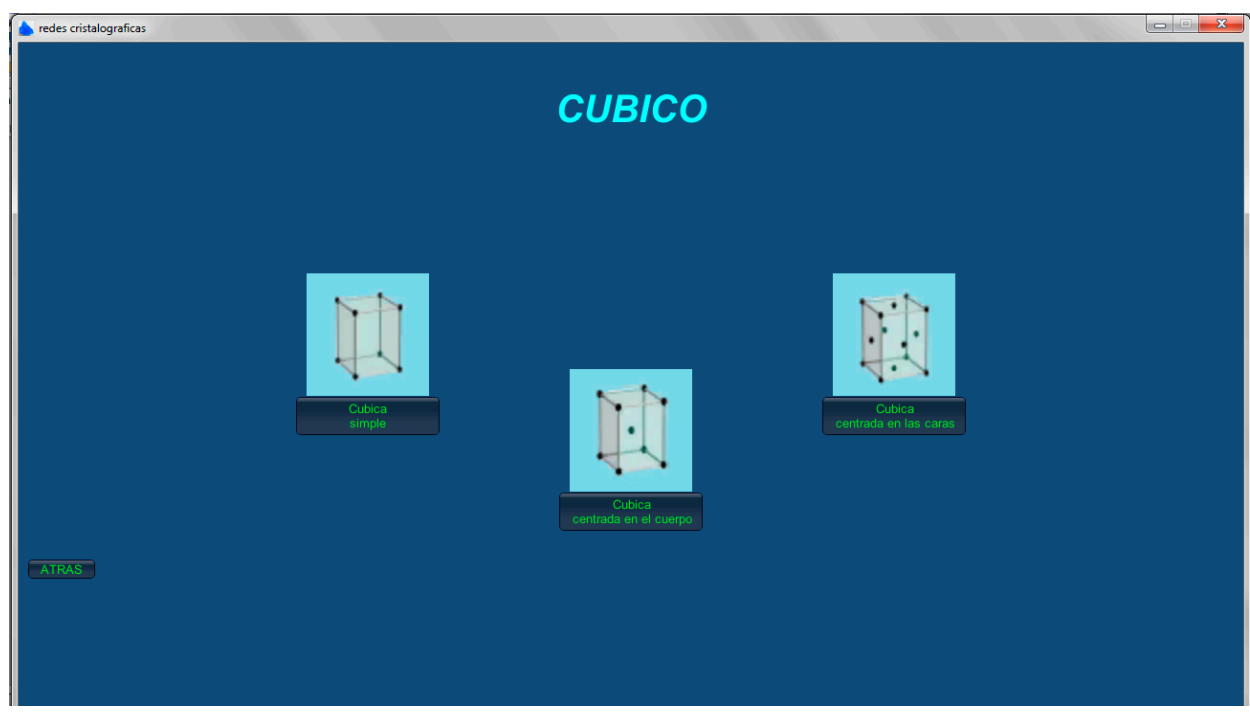

Figure 3. Screen of the Didactic Virtual Tool showing crystal cubic systems.

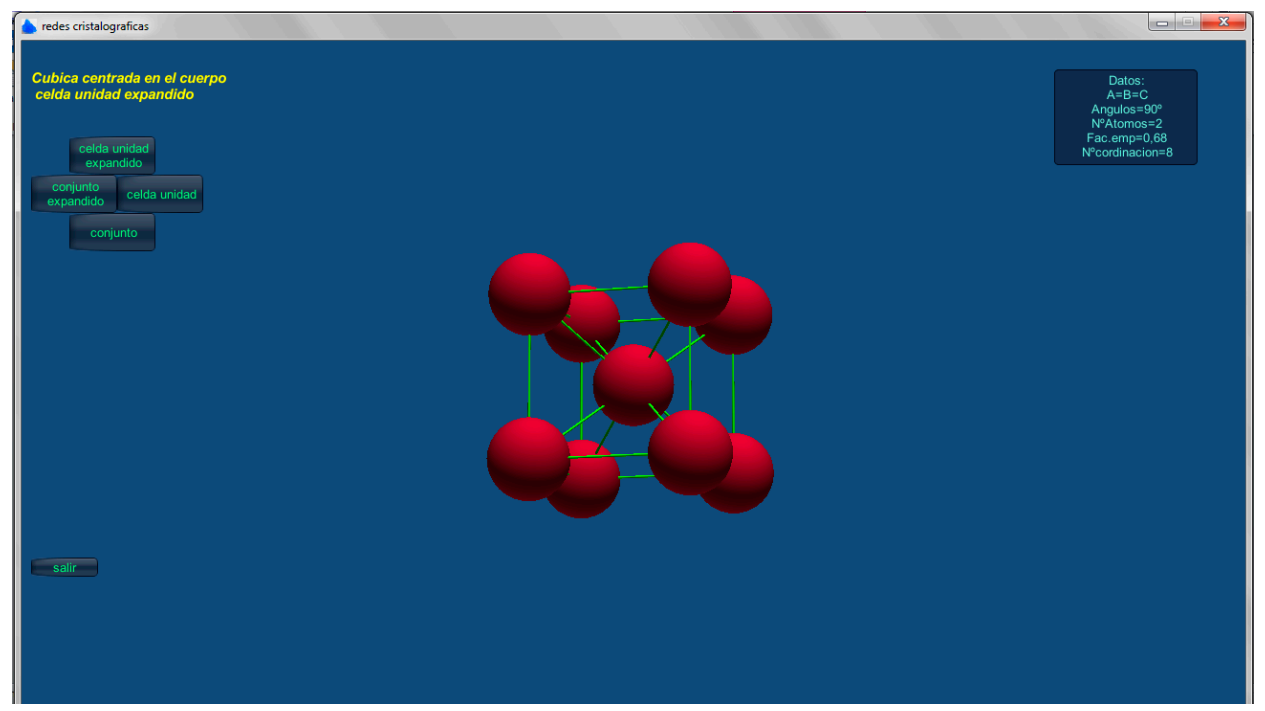

Figure 4. Options included in the DVT for each spatial lattice: expanded unit cell.

For the teaching-learning process, the most relevant issue is that students interact in real time with the unit cell or crystal system by using the DVT. The interactivity feature in DVTs is really helpful for the user spatial comprehension [28]. With this in mind, the DVT allows each lattice to be rotated, turned, and placed where the user desires (Figure 6). Furthermore, the DVT allows students to perform cross sections of the lattice to enhance the understanding of the spatial position of the crystal system. As an example, Figure 7 shows diverse cross sections of a spatial lattice corresponding to a BCC (Figure 7a) and FCC (Figure 7b). From these figures the reader can easily comprehend that the 
spatial visualization of this type of lattice is not an easy task, and thus he/she can also understand the difficulties that can arise when this issue is explained without a DVT.

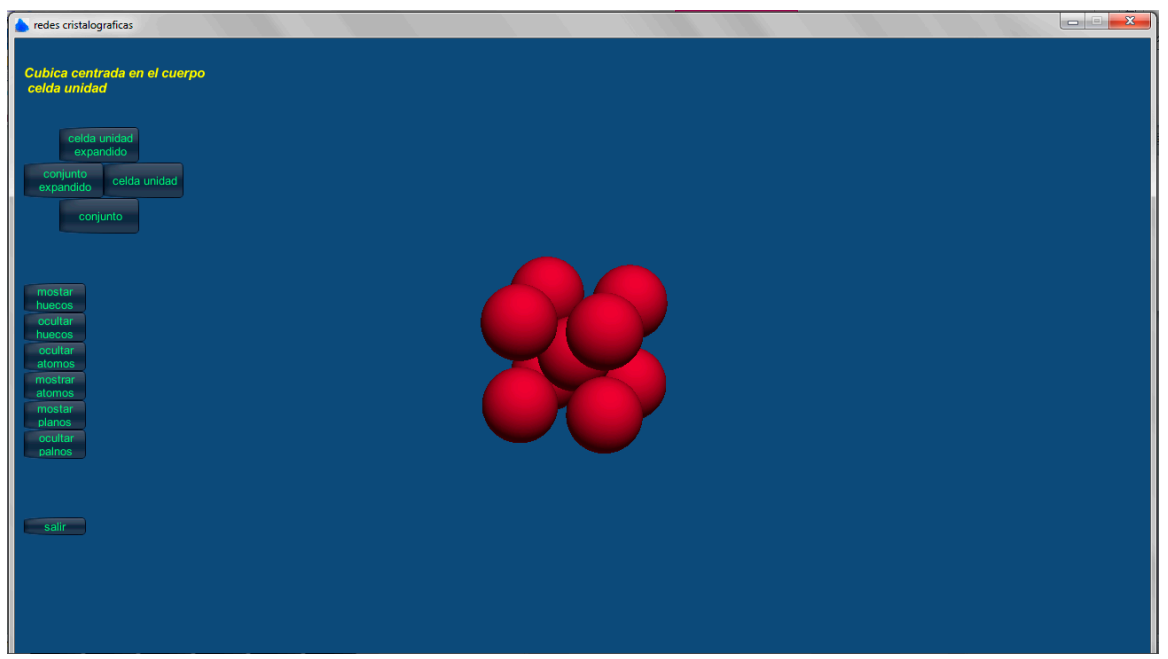

(a)

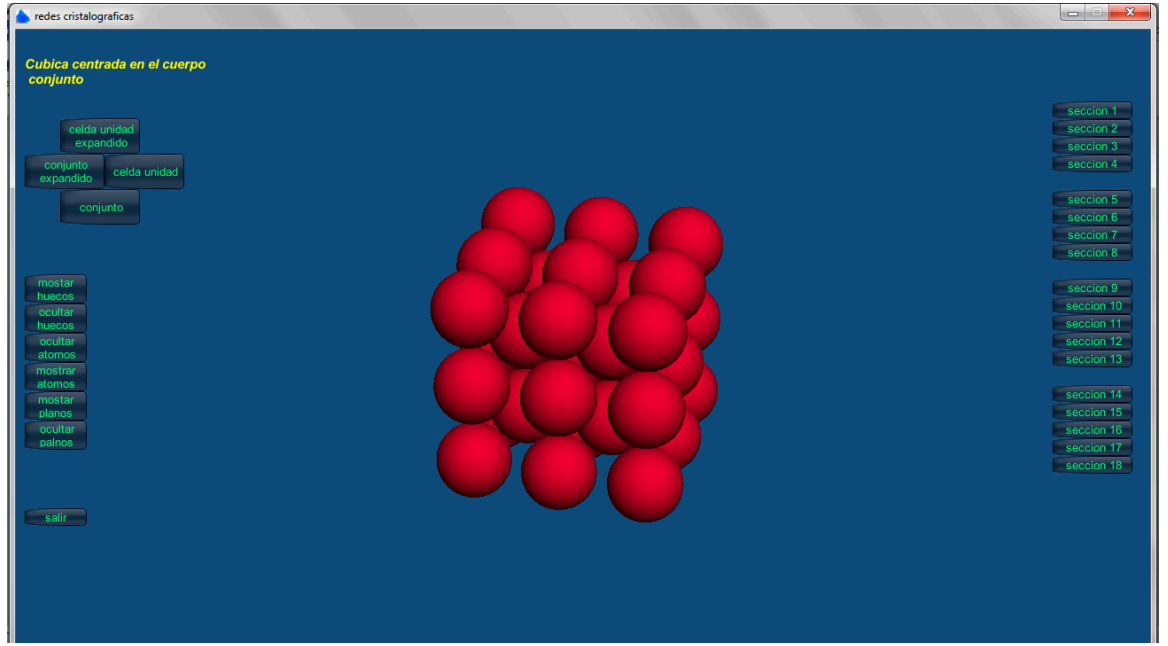

(b)

Figure 5. Options included in the DVT for each spatial lattice: (a) real unit cell; (b) real global lattice.
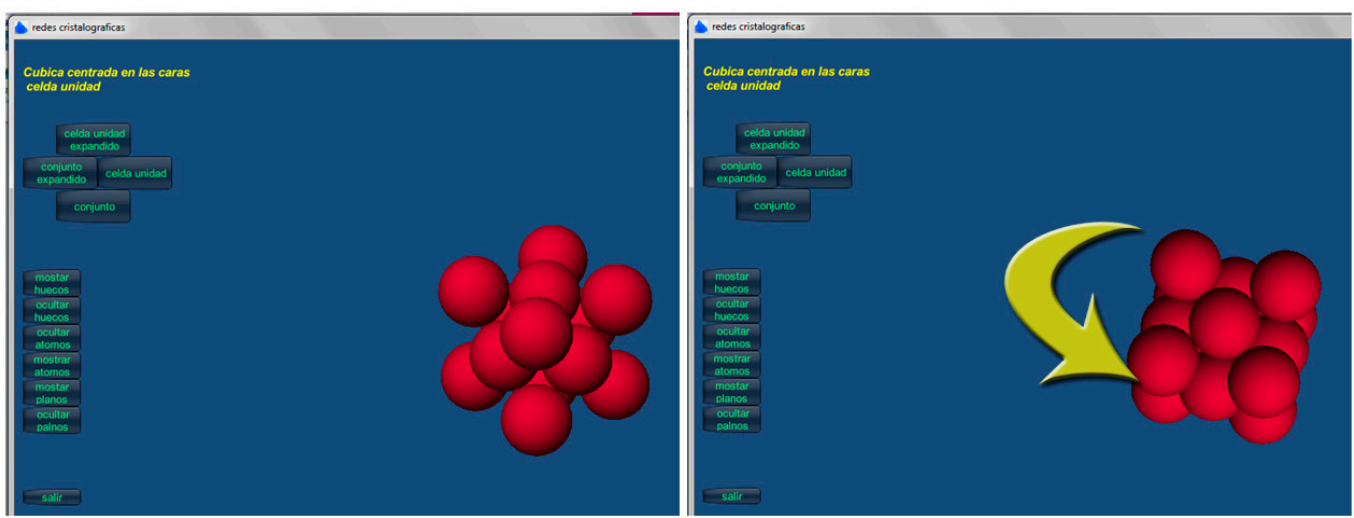

Figure 6. Rotation of a unit cell by using the interactivity feature in real time. 


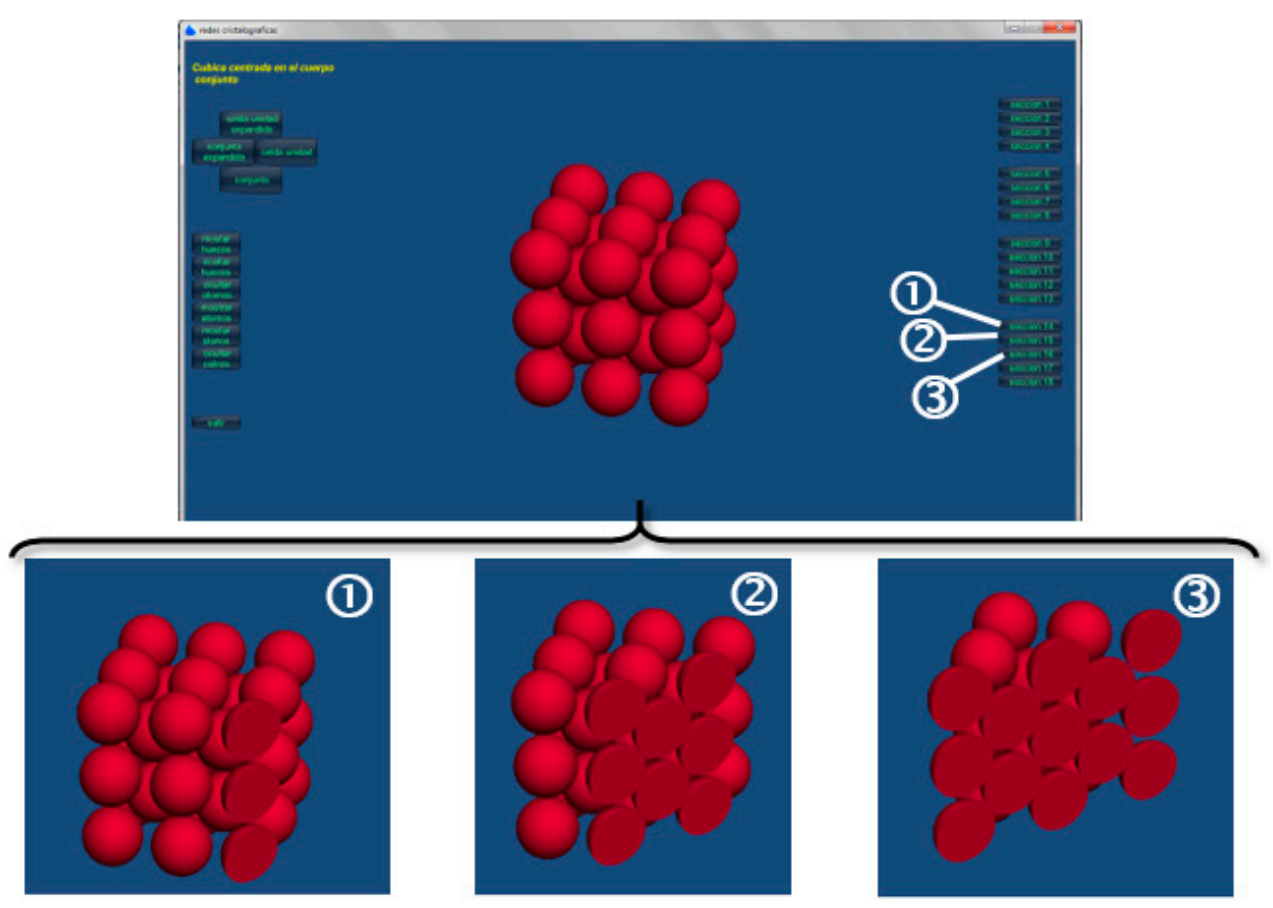

(a)

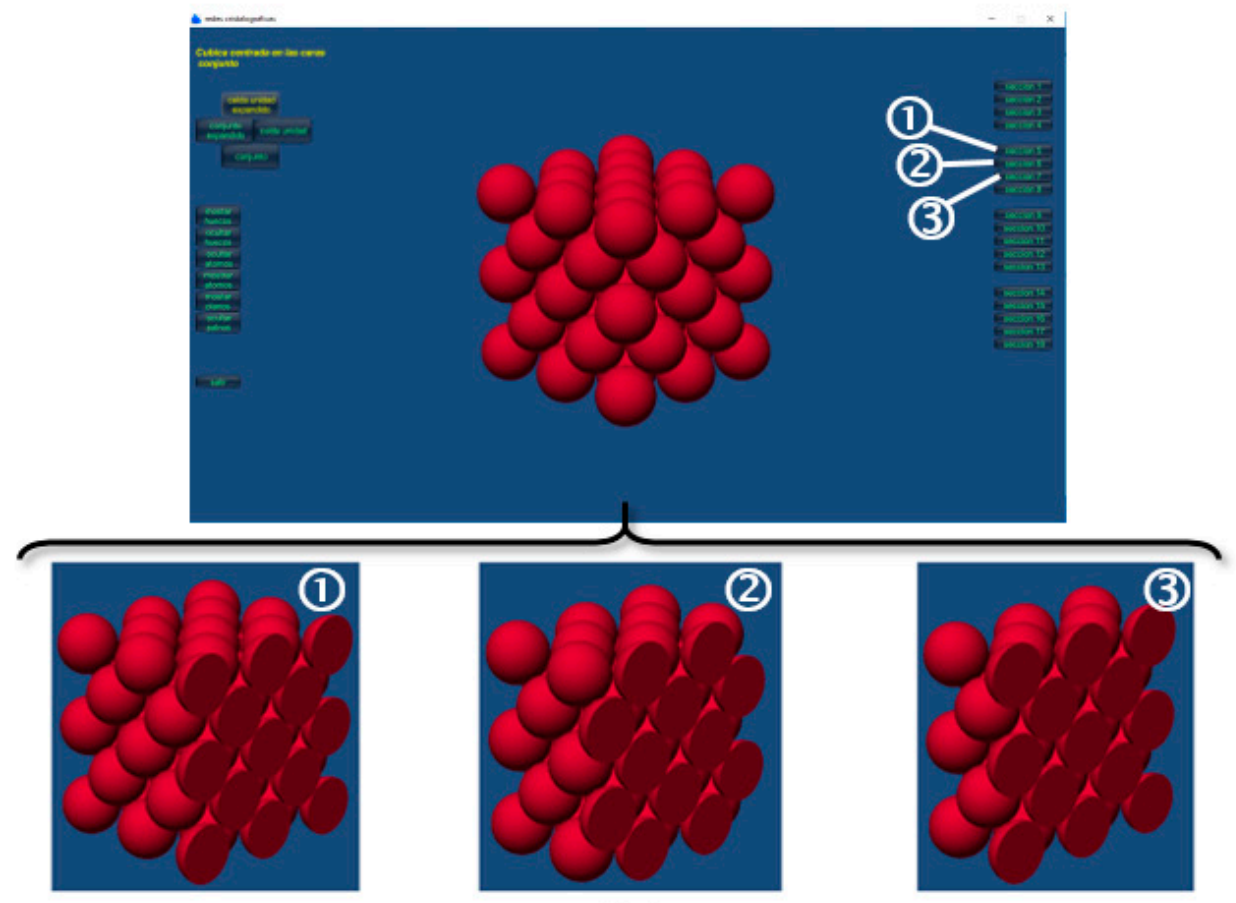

(b)

Figure 7. Cubic crystal structures: (a) general view and three cross sections of the body centred cubic (BCC) lattice; (b) general view and three cross sections of the face centred cubic (FCC) lattice.

\section{Methodology}

Active learning, as compared with the traditional style based on passive methodologies, involves a higher work effort for both students and instructors. Despite this, active learning experiences are positively valuated by both instructors and students $[29,30]$. The methodology presented in this paper for the teaching-learning process of crystal systems is based on active learning, following the stages 
depicted in Table 1: (i) master class; (ii) DVT by means of a self-leaning process; (iii) problem solving by means of cooperative learning.

Table 1. Phases of the proposed methodology.

\begin{tabular}{ccl}
\hline Phase & Time & \multicolumn{1}{c}{ Description } \\
\hline 1 & $2 \mathrm{~h}$ & $\begin{array}{l}\text { Theoretical explanation of the crystal systems: explanation of the } \\
\text { theory basics of the topic, formulation, crystallographic directions, } \\
\text { Miller indexes for crystallographic planes, etc. }\end{array}$ \\
\hline 2 & $0.5 \mathrm{~h}$ & $\begin{array}{l}\text { Application of the DVT: spatial understanding of each one of the } \\
\text { crystal systems and Bravais lattices. The use of the Didactic Virtual Tool } \\
\text { (DVT) will be developed on an individual level to enhance a } \\
\text { self-learning process. }\end{array}$ \\
\hline 3 & $2 \mathrm{~h}$ & $\begin{array}{l}\text { Exercises: students will solve a collection of exercises in small groups } \\
\text { of 3-4 students, enhancing a collaborative learning process and } \\
\text { peer-learning. }\end{array}$ \\
\hline
\end{tabular}

Firstly, the instructor teaches a master class of approximately $2 \mathrm{~h}$ demonstrating all the theoretical basic concepts of the topic. In this phase, the traditional passive teaching must be avoided, aiming for a dynamic response from the students (active methodology). To achieve this goal, the authors have developed some incomplete notes that students must complete as the master class is carried out. In this way, students stop being mere spectators as they must be actively involved in the learning environment.

Following this, students interact with the DVT to spatially understand the crystal systems. Authors consider that the best option is to develop this phase on an individual level, since each student needs a different time to reach a spatial understanding of this type of crystal lattice. To make this self-learning process effective, the DVT must be intuitive and easy to use.

Finally, the instructor will deliver a collection of exercises to be solved in small groups (3-4 students) to enhance the cooperative learning process. This is the last stage of the proposed methodology and it is of paramount importance that the learning process is as efficient as possible, thus the authors consider that working in groups to solve individual doubts is the best option. Equally, according to previous studies, small groups of 3-4 people can contribute to a more efficient cooperative learning [31], thereby enhancing the peer-learning process. According to previous studies [32], this is an aspect that facilitates the resolution of spatial geometric problems. In Figure 8, a scheme of the proposed methodology is represented.

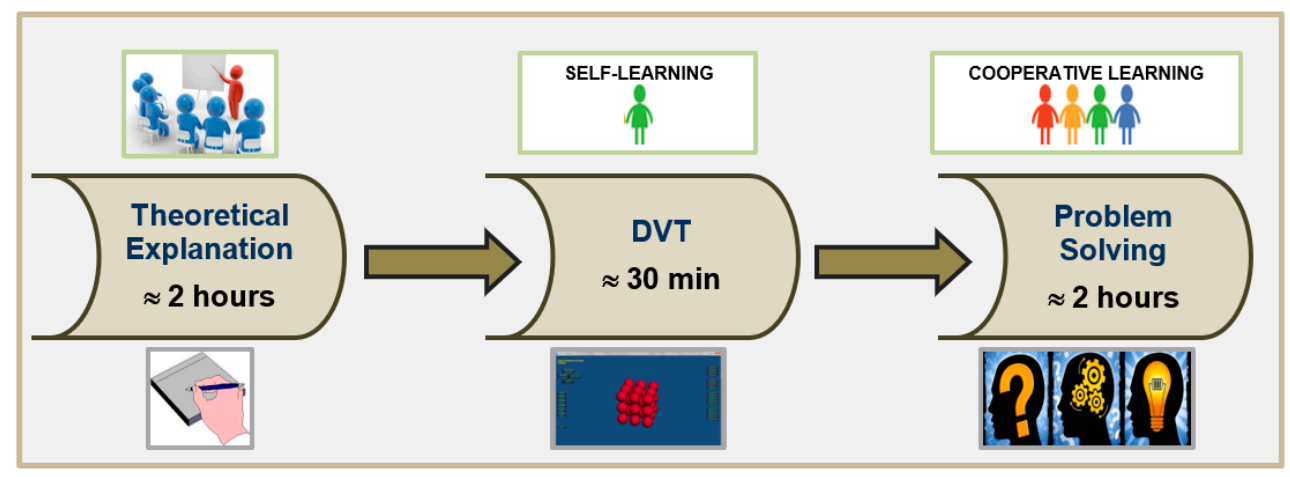

Figure 8. Scheme of the proposed methodology.

\section{Students' Opinions}

This section includes the students' opinions after using the previously explained DVT. To do so, a quasi-experimental research was carried out on a total of 40 students enrolled on the Materials 
Science and Engineering course (second course in the Mechanical Engineering Degree). Some of the questions included in the survey are directly related to the design of the tool and others to the methodology applied (Table 2). The survey results show the importance of the design of DVTs (Figure 9). On one hand, the DVT was well rated with regard to its didactic usefulness, as is reflected by the average values ( 9.5 points out of 10 with a standard deviation of 0.33 ), and its ease of use (9 points out of 10 with a standard deviation of 0.28 ). Thus, the results show that the students consider that the DVT is an intuitive application. On the other hand, the results reveal that the tool does not motivate all the students to the same level ( 7.5 points out of 10 with a standard deviation of 0.67$)$. In all the answers, the standard deviation is low, but in the case of learning motivation, the deviation is twice that obtained in the other questions. These results suggest that students' motivation is in essence subjective, and in addition, they demonstrate that what is highly motivating for one student may not rouse the same interest in others.

Table 2. Questions included in the students' survey.

\begin{tabular}{cll}
\hline Number & \multicolumn{1}{c}{ Question } & \multicolumn{1}{c}{ Response } \\
\hline 1 & $\begin{array}{l}\text { Rate from 1 to 10 the following DVT } \\
\text { features: }\end{array}$ & $\begin{array}{l}\text { (A) Interactivity } \\
\text { (B) Ease of use } \\
\text { (C) Didactic usefulness } \\
\text { (D) Motivation } \\
\text { (E) Design }\end{array}$ \\
\hline 2 & $\begin{array}{l}\text { Rate from 1 to 10 the methodology } \\
\text { proposed for learning crystalline systems. }\end{array}$ & $\begin{array}{l}\text { (A) Master class } \\
\text { (B) DVT } \\
\text { (C) Problem solving }\end{array}$ \\
\hline 3 & Possible improvements of the DVT & Comments:
\end{tabular}

Motivation in learning is one of the most analyzed topics in education [33-35] as it seems to be linked with academic performance. For this reason, the results of this survey which are related to this aspect deserve to be analysed in detail. The relatively low motivation can be explained in two possible ways: (i) students do not feel motivated by the topic itself; and (ii) the DVT does not motivate students due to an unattractive design (the rate was 8 points out of 10, Figure 9). Both factors are possible, however, taking into account the following facts: (i) this topic, crystal systems, is included in the final exam of the subject; and (ii) the DVT can help students to spatially understand all the crystal lattices, the authors consider that the most influential factor for the observed low student motivation is the tool design. In addition, considering that students had previously handled other (more sophisticated) DVTs related to virtual labs of Material Science [36-39], the comparison between them and this DVT could be the main cause of the low valuation given to the design feature of the exposed DVT (the lowest one in Figure 9). Therefore, a direct relationship exists between the design of $a$ VT and the motivation generated in users to keep on using it. Consequently, both aspects (design and motivation) are really important in DVTs $[40,41]$ and they should be taken into account in the early design phase of any didactic tool.

The valuation given by students of the other DVT features is really promising, given that all of them (interactivity, ease of use, and didactic use) are rated between 9 and 9.5 out of 10 (Figure 9). These results suggest that the DVT presented in this paper-in a global sense-helps students to acquire a better spatial comprehension of crystal systems. Furthermore, the authors verified that the presented DVT helps instructors to teach crystal systems, since the contents involved in such a topic are difficult to explain orally. This way, the DVT accomplishes its intended function. 


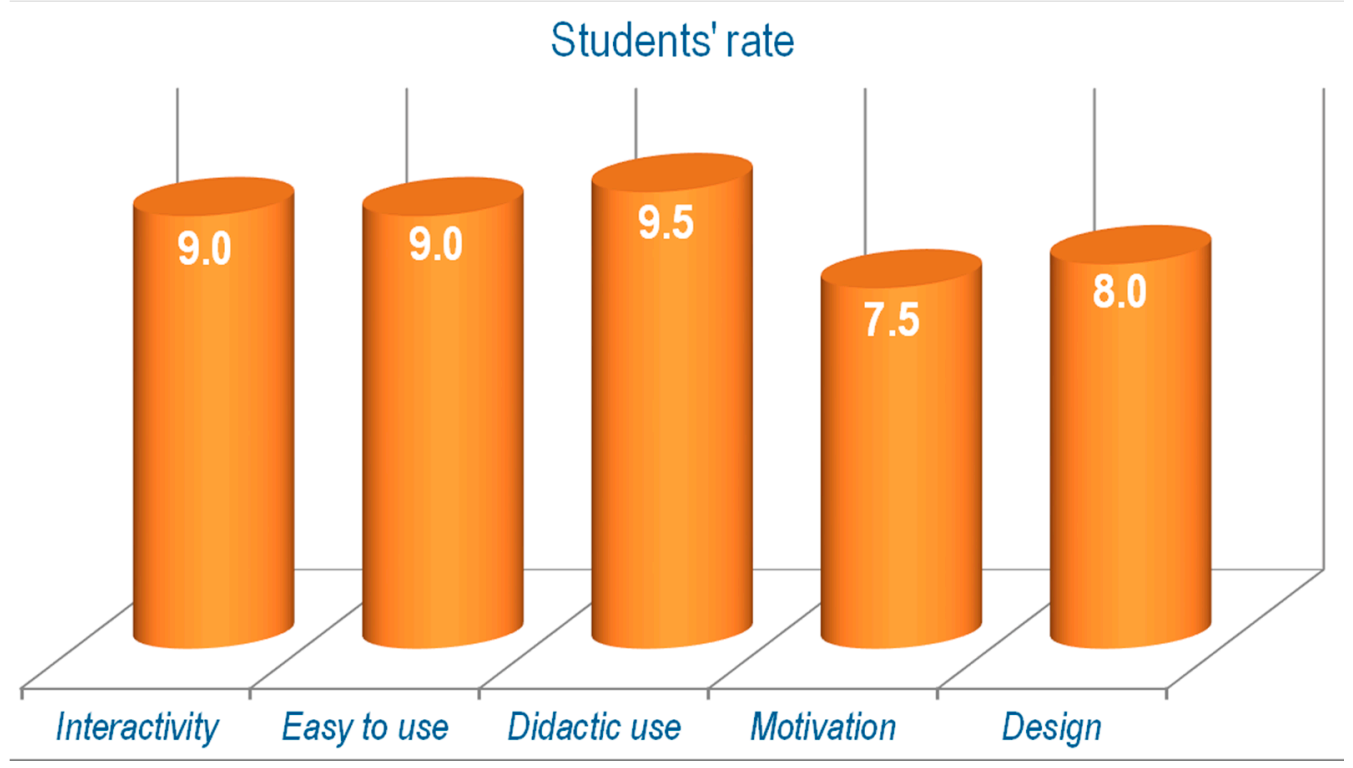

Figure 9. Ratings of students' answers to the survey.

Additionally, the survey results suggest that students are in agreement with the methodology used (Figure 8), given that they have evaluated all the phases-master class, DVT, and problem solving - with a rating higher than 8 out of 10 . The phase with the highest rating (slightly higher than the others) is the last one, where students cooperate among themselves. The ratings given for each phase (out of 10) are as follows: 8.5 master class, 8.5 DVT, and 9 problem solving. Finally, with regards to the third question included in Table 2, students also highlight that the following improvements could be made:

- Amend small typos;

- Indicate the place of octahedral and tetrahedral interstitial sites;

- Include the structure HCP in the DVT;

- Implement the application of the Miller indexes and the crystallographic directions.

The authors consider the previously depicted students' improvement suggestions to be very useful and interesting, and hence, are trying to implement all of them in a new version of the DVT. Furthermore, they are updating the aesthetic of the tool with the ultimate aim of enhancing learning motivation in students.

\section{Conclusions}

A Didactic Virtual Tool (DVT) is presented in this paper. This didactic tool, developed with the software Unity ${ }^{\circledR}$, can be used in the teaching-learning process of crystal systems. Taking into account the difficulty of spatial understanding related to this topic, the presented DVT helps student to visualize the spatial arrangements of atoms, thereby making the teaching process easier.

From the developed survey, it was confirmed that a direct relationship exists between the virtual tool design and the motivation generated in the user to keep on using it. Therefore, in this paper the relevance of the design of any didactic virtual resource to make it not only educative but also motivating is highlighted. To achieve this goal, it is recommended to conduct student surveys periodically to detect any decrease in motivation, and if necessary, to carry out the appropriate improvements in a new version of the DVT using the most modern commercial software possible. 
Author Contributions: D.V. and M.P.R. design the virtual tool; D.V., M.P.R. and M.L. analyzed the data and wrote the paper.

Funding: This research was funded by the University of Salamanca, grant number ID2015/0267.

Conflicts of Interest: The authors declare no conflict of interest.

\section{References}

1. Asbhy, M.F.; Jones, D.R.H. Engineering Materials 2: An Introduction to Microstructures and Processing, 4th ed.; Editorial Butterworth Heinemann: Oxford, UK, 2013.

2. Callister, W.D. Materials Science and Engineering: An Introduction, 7th ed.; John Wiley \& Sons: New York, NY, USA, 2007; ISBN 978-0-471-73696-7.

3. Mangonon, P.L. The Principles of Materials Selection for Engineering Design; Prentice Hall International: Upper Saddle River, NJ, USA, 1999; ISBN 978-0132425957.

4. Shackelford, J.F. Introduction for Materials Science for Engineers, 4th ed.; Prentice-Hall International: Upper Saddle River, NJ, USA, 1998; ISBN 978-0130112873.

5. Smith, W.F.; Hashemi, J. Foundations of Materials Science and Engineering, 5th ed.; McGraw-Hill Education: New York, NY, USA, 2009.

6. Hsi, S.; Linn, M.C.; Bell, J.E. The role of spatial reasoning in engineering and the design of spatial instruction. J. Eng. Educ. 1997, 86, 151-158. [CrossRef]

7. Garmendia, M.; Guisasola, J.; Sierra, E. First-year engineering students' difficulties in visualization and drawing tasks. Eur. J. Eng. Educ. 2007, 32, 315-323. [CrossRef]

8. Vergara, D.; Rubio, M.P.; Lorenzo, M. New computer teaching tool for improving students' spatial abilities in continuum mechanics. IEEE Technol. Eng. Educ. 2012, 7, 44-48.

9. Meagher, K.A.; Doblack, B.N.; Ramirez, M.; Davila, L.P. Scalable nanohelices for predictive studies and enhanced 3D visualization. J. Vis. Exp. 2014, 93, e51372. [CrossRef] [PubMed]

10. Vergara, D.; Rubio, M.P.; Lorenzo, M. A virtual environment for enhancing the understanding of ternary phase diagrams. J. Mater. Educ. 2015, 37, 93-101.

11. Rafi, A.; Khairul, A.; Samad, A.; Maizatul, H.; Mahadzir, M. Improving spatial ability using a web-based virtual environment (WbVE). Autom. Const. 2005, 14, 707-715. [CrossRef]

12. Vergara, D.; Lorenzo, M.; Rubio, M.P. Virtual environments in materials science and engineering: The students' opinion. In Handbook of Research on Recent Developments in Materials Science and Corrosion Engineering Education, 1st ed.; Lim, H., Ed.; IGI Global: Hershey, PA, USA, 2015; pp. 148-165.

13. Öz, C.; Serttaş, S.; Ayar, K.; Fındık, F. Effect of virtual welding simulator on TIG welding training. J. Mater. Educ. 2015, 37, 197-218.

14. Wang, P.; Wu, P.; Wang, J.; Chi, H.-L.; Wang, X. A critical review of the use of virtual reality in construction engineering education and training. Int. J. Environ. Res. Public Health 2018, 15, 1204. [CrossRef] [PubMed]

15. Sorby, S.A.; Baatmans, B.J. The development and assessment of a course for enhancing the 3-D spatial visualization skills of first year engineering students. J. Eng. Educ. 2000, 301-307. [CrossRef]

16. Crown, S.W. Improving visualization skills of engineering graphics students using simple javascript web based games. J. Eng. Educ. 2001, 347-355. [CrossRef]

17. Leopold, C.; Górska, R.A.; Sorby, S.A. International experiences in developing the spatial visualization abilities of engineering students. J. Geom. Graph. 2001, 15, 271-298.

18. Rafi, A.; Samsudin, K.A.; Ismail, A. On improving spatial ability through computer-mediated engineering drawing instruction. Educ. Technol. Soc. 2006, 9, 149-159.

19. Carbonell-Carrera, C.; Hess, M. Spatial orientation skill improvement with geospatial applications: Report of a multi-year study. ISPRS Int. J. Geo-Inf. 2017, 6, 278. [CrossRef]

20. Buckley, J.; Seery, N.; Canty, D. A heuristic framework of spatial ability: A review and synthesis of spatial factor literature to support its translation into STEM education. Educ. Psychol. Rev. 2018, 1-26. [CrossRef]

21. Blatov, V.A.; Shevchenko, A.P.; Proserpio, D.M. Applied topological analysis of crystal structures with the program package ToposPro. Cryst. Growth Des. 2014, 14, 3576-3586. [CrossRef]

22. Arribas, V.; Casas, L.; Estopa, E.; Labrador, M. Interactive PDF files with embedded 3D designs as support material to study the 32 crystallographic point groups. Comput. Geosci. 2014, 62, 53-61. [CrossRef] 
23. Casas, L.; Estop, E. Virtual and printed 3d models for teaching crystal symmetry and point groups. J. Chem. Educ. 2015, 92, 1338-1343. [CrossRef]

24. Sancho, E.; Araújo, E.; Conde, W.; Saraiva, I.; Maia, R.C.; Oliveira, L.M.; Sales, J.; Sombra, A.S.; Albuquerque, J.S. Models manufacturing of crystal systems: an introduction to ceramic materials. Mater. Sci. Forum 2018, 912, 280-284. [CrossRef]

25. Stukowski, A. OVITO: Open Visualization Tool. Available online: http://www.ovito.org/ (accessed on 19 September 2018).

26. Chan, C.; Fok, W. Evaluating learning experiences in virtual laboratory training through student perceptions: A case study in electrical and electronic engineering at the University of Hong Kong. Engl. Educ. 2009, 4, 70-75. [CrossRef]

27. Smith, W.F. Ciencia e Ingeniería de Materiales; Mc Graw Hill: New York, NY, USA, 2004; ISBN 84-481-2956-3.

28. Zander, S.; Wetzel, S.; Bertel, S. Rotate it! Effects of touch-based gestures on elementary school students' solving of mental rotation tasks. Comput. Educ. 2016, 103, 158-169. [CrossRef]

29. Courcel, M.J.; García, A.; Rodríguez, A.; Romero, M.A. What do university students think about the new active methodologies of education? Revista de Curriculum y Formación del Profesorado 2009, 13, 305-319.

30. León, M.J.; Crisol, E. Questionnaire design (OPPUMAUGR y OPEUMAUGR): The views and perceptions of teachers and students on the use of actives methodologies at the university. Revista de Curriculum y Formación del Profesorado 2011, 13, 305-319.

31. Smith, K.A. Cooperative learning: Making "groupwork" work. Dir. Teach. Learn. 1996, 67, 71-82. [CrossRef]

32. Hwang, W.-Y.; Hu, S.-S. Analysis of peer learning behaviors using multiple representations in virtual reality and their impacts on geometry problem solving. Comput. Educ. 2013, 62, 308-319. [CrossRef]

33. Conradty, C.; Bogner, F.X. Hypertext or textbook: Effects on motivation and gain in knowledge. Educ. Sci. 2016, 6, 29. [CrossRef]

34. LaForce, M.; Noble, E.; Blackwell, C. Problem-based learning (PBL) and student interest in stem careers: The roles of motivation and ability beliefs. Educ. Sci. 2017, 7, 92. [CrossRef]

35. Arango-López, J.; Cerón, C.C.; Collazos, C.A.; Gutiérrez, F.L.; Moreira, F. CREANDO: Tool for creating pervasive games to increase the learning motivation in higher education students. Telemat. Inform. 2018, in press.

36. Vergara, D.; Rubio, M.P.; Lorenzo, M. Interactive virtual platform for simulating a concrete compression test. Key Eng. Mater. 2014, 572, 582-585. [CrossRef]

37. Vergara, D.; Rubio, M.P. The application of didactic virtual tools in the instruction of industrial radiography. J. Mater. Educ. 2015, 37, 17-26.

38. Vergara, D.; Rubio, M.P.; Prieto, F.; Lorenzo, M. Enhancing the teaching/learning of materials mechanical characterization by using virtual reality. J. Mater. Educ. 2016, 38, 63-74.

39. Vergara, D.; Rubio, M.P.; Lorenzo, M. New approach for the teaching of concrete compression tests in large groups of engineering students. J. Prof. Issues Eng. Educ. Pract. 2017, 143. [CrossRef]

40. Vergara, D.; Rubio, M.P.; Lorenzo, M. On the design of virtual reality learning environments in engineering. Multimodal Technol. Interact. 2017, 1, 11. [CrossRef]

41. Chasanidou, D. Design for motivation: Evaluation of a design tool. Multimodal Technol. Interact. $2018,2,6$. [CrossRef]

(c) 2018 by the authors. Licensee MDPI, Basel, Switzerland. This article is an open access article distributed under the terms and conditions of the Creative Commons Attribution (CC BY) license (http://creativecommons.org/licenses/by/4.0/). 